\title{
SHOULD FINLAND AND SWEDEN FORM A MONETARY UNION?
}

\author{
Working Paper Series in Economics and Finance, No. 224 \\ February 1998
}

\author{
Lars Jonung \\ Stockholm School of Economics \\ Box 6501 \\ S-113 83 Stockholm \\ Sweden \\ E-mail: nejl@hhs.se
}

\author{
Fredrik Sjöholm \\ Stockholm School of Economics \\ Box 6501 \\ S-113 83 Stockholm \\ Sweden \\ E-mail: japfs@hhs.se
}

\begin{abstract}
This paper surveys the future exchange rate policy of Finland and Sweden using the theory of optimal currency areas as a framework for the analysis. We examine which countries are most suitable to form a currency union with Finland and Sweden. The Finnish and Swedish economies display great similarities regarding industrial structure, business cycle patterns, migration and the design of economic policies. There are substantial differences between on the one hand Finland and Sweden, and on the other, many EU countries which are potential members of a future EMU. Our calculations give support for of a Finnish-Swedish currency union and put a Finnish-Swedish membership of the EMU into question. Our results stress the importance of Finnish-Swedish co-operation in monetary matters. This could take many forms, of which a monetary union is one.
\end{abstract}

JEL classifications: F33

Keywords: Monetary integration; optimum currency areas; Finland; Sweden. 


\section{SHOULD FINLAND AND SWEDEN FORM A CURRENCY UNION? ${ }^{1}$}

Finland and Sweden face today a unique choice of exchange rate system. Should they become members of the planned European Monetary Union the EMU, or should they choose some alternative arrangement? It is high time for a decision. In December 1995, the meeting of ministers in Madrid decided that the European Economic and Monetary Union, EMU, should be introduced in the year 2002. Both Sweden and Finland have declared their interest in becoming members of this union. Finland has entered the European Exchange Rate Mechanism (ERM), as one step in its approach to the EMU. Swedish participation in the ERM has also been discussed but been postponed due to strong domestic opposition. At the same time, many economists and politicians have a sceptical attitude to the EMU; this is more pronounced in Sweden than in Finland.

The recent debate on the advantages and disadvantages of the EMU among Finnish and Swedish economists has been lively. Participation in a monetary or a currency union such as the EMU is assumed to lead to reduced transaction costs and exchange rate fluctuations, and thus to an increased trade with increased investment. Another advantage of Finland and Sweden joining the EMU would be that this would contribute to low inflation.

The major argument against joining the EMU is that this would involve a loss of monetary independence. The Finnish and Swedish currencies would disappear when they were replaced by the Euro. Changes in the exchange rate could no longer function as "buffers" or "insurance" against domestic and foreign disturbances. The risk is then that asymmetrical disturbances, i.e. shocks that affect one member of a currency union differently from the other member countries, will lead to increased unemployment and stagnation. These shocks can be either endogenous or exogenous.

Endogenous shocks, i.e. shocks which are generated inside the country, are caused principally by economic policies. Exogenous shocks can also be due to political events, for example the German reunification and the collapse of the Soviet Union, but usually they originate from international changes in the supply and demand for goods and production factors. This type of shock is difficult to counter with a common economic policy in a monetary union, where each member has given up its possibility of carrying out an independent exchange-rate policy. As we will demonstrate, the structure of the Swedish and Finnish economies exhibits unique features compared to the other EMU countries, which increases the risk of asymmetric shocks. Thus it becomes more advantageous to remain outside a European monetary union, and to be able to counter asymmetric shocks with the help of a flexible exchange rate.

\footnotetext{
${ }^{1}$ We have received valuable comments from Hans Blomqvist, Ari Kokko, Markku Kotilainen and Hans Tson Söderström. Financial support has been given by the Svenska ICC Nicolin Foundation. This study is inspired by our report for the Finnish government commission on EMU.
} 
The aim of this article is to shed light on the choice of exchange rate system facing Finland and Sweden adopting the theory of optimum currency areas as framework for our discussion. This theory has had a major influence on the debate about the proper choice of currency area. The article is arranged as follows. Section I briefly reviews theories dealing with optimum currency areas. In the next section we investigate, on the basis of these theories, the relations between Finland and Sweden and between these two countries and other industrial countries, of which some will become members of the EMU. In Section III we discuss the advantages of a Finnish-Swedish monetary union and present our conclusions.

\section{Theories of optimum currency areas}

There is no standard theory of optimum currency areas; rather several approaches exist inspired by Mundell's (1961) seminal article. A number of different criteria, some of them contradictory, have been proposed which should be fulfilled for a currency union to be a suitable arrangement. ${ }^{2}$ Table 1 displays the criteria, which we consider to be the most central ones. We find it proper to divide them into two groups; namely those which refer to the particular country (country-specific criteria) and those which refer to the choice of countries which are suitable to join a currency union (union-specific criteria).

(Table 1 about here.)

A currency union implies, by definition, that its members have given up their own currencies, and thus the possibility of using changes in the exchange rate as an instrument of economic policy. If adjustments of the exchange rate cannot be used to counter disturbances, it is important to have alternative adjustment mechanisms. Flexibility of wages and prices is one such mechanism. The more flexible the wages and prices in a country, the lower is the cost of abandoning the domestic currency and giving up exchange-rate adjustments as a means of countering asymmetrical shocks.

Another country-specific factor is the degree of product diversification. A country with a high degree of product diversification, i.e. with a large number of different products, is seen as a good candidate for a currency area. An asymmetric shock, which affects one particular sector, has a limited total effect on a well-diversified economy (Kenen (1969)).

A number of union-specific criteria can be derived from the theory of optimum currency areas. As mentioned earlier, it is desirable to have alternative adjustment mechanisms when a country has given up the possibility of exchange-rate adjustments. A high mobility of production within the union is one such union-specific mechanism. When economic disturbances occur, the adjustment process can then be facilitated by migration of labour and capital between the members of a currency union.

\footnotetext{
${ }^{2}$ For a review, see for example Tavlas (1993).
} 
Countries with a similar industrial structure will be affected in a similar way by sectorspecific asymmetrical disturbances. Countries which are members of a currency union should therefore exhibit the same sort of industrial structures (Mundell (1961)). Cyclical covariation in economic activities indicates that the countries are subject to common economic shocks, which reduces the significance of exchange-rate adjustments.

The rates of inflation should be relatively similar in the countries which intend to form a currency union (Fleming (1971)). Different rates of inflation indicate differences in the structure of the economy and/or in the preferences as regards the conduct of economic policies in the participating countries. In a currency union, the rate of inflation will be similar in the member countries. For countries which have the same historical inflation patterns, this convergence can be achieved relatively easily. For countries with different historical rates of inflation, this convergence can be expected to be more difficult to bring about.

If countries are to be able to form a well functioning currency union, it is desirable that there should be agreement about preferences in matters of political economy, as regards e.g. unemployment and inflation, since a currency union demands convergence in stabilisation policies. If the countries have already been following similar economic policies, it may be assumed that the change-over will take place relatively painlessly.

Political factors are crucial for the formation of a currency union. Mintz (1970) argues that the most important criterion for monetary integration is the political will. Cohen (1993) verifies this suggesting that political factors dominate over economic ones in currency unions. Consequently a currency union presupposes a strong political support from the general public in favour of a monetary union. This support depends upon factors such as geographical proximity between the member countries, cultural, religious, social and linguistic similarities, etc. $^{3}$

\section{What would be an optimum currency area for Sweden and Finland?}

The criteria in Table 1 are relative ones. In addition, several of them are difficult to measure. Consequently it is necessary to observe great caution when they are used to illustrate alternative monetary policies. Another problem concerns the use of historical data. Entry into a currency union will involve considerable changes in the rules of the game for economic policy in the member countries. Membership in the European monetary union will probably compel both public and politicians to change their expectations and their behaviour, which may be reflected in e.g. more flexible wages and prices.

It is probable that the "similarity" in a number of the criteria in Table 1 will increase as a

\footnotetext{
${ }^{3}$ The Scandinavian currency union, which comprised Sweden, Denmark and Norway, came into being as a result of strong public support. See Bordo and Jonung (1997).
} 
consequence of membership in a currency union such as EMU. ${ }^{4}$ How difficult and timeconsuming this process is will probably depend on historical conditions. For countries with, for example, a previously low flexibility in wages and prices, it is reasonable to assume that the process will be relatively cumbersome. Historical data can tell us something about the probable difficulty of adjusting membership in a monetary union.

Next we will study Finland and Sweden using the criteria in Table 1.

\section{Country-specific criteria}

The degree of wage and price flexibility. The greater the flexibility of a country's wages and prices, the smaller the risk involved in giving up the domestic currency. In Sweden, the levels of real wages exhibited prior to the 1990s a relatively high degree of flexibility. An increased rate of unemployment resulted in a relatively large drop in real wages. However, real wage movements in Sweden have been achieved principally via adjustments of the nominal exchange rate, i.e. by devaluations. There are strong indications that nominal wages exhibit considerably inflexibility. For example, the wage negotiations in 1995 and 1996 resulted in a rate of nominal wage increase which exceeded the European average, even though the Swedish unemployment was at least as high as the European level.

Nominal wage rises have been lower in Finland than in Sweden recently. This could indicate that wage flexibility is somewhat higher in Finland. However, unemployment is also higher in Finland than in Sweden. With flexible wages, the very high unemployment in Finland should rather cause a lower nominal wage level, not just low positive increases of wages. Our conclusion is that the degree of wage flexibility is rather low in both Finland and Sweden.

The degree of product diversification. A traditional way of measuring the degree of product diversification in an economic system is to investigate the fraction of the total production occupied by different sectors. We therefore construct a Herfindahl index for a number of OECD countries.

Produktdiversification $_{i}=100 * \sum_{j=1}^{n} s_{j}^{2}$

where $s_{j}$ is the fraction occupied by sector $j$ in total manufacturing value added in country $i$. The higher the value of this measure, which can vary between 0 and 100, the smaller is the degree of product diversification. Data from 19 different manufacturing industries are used at three- and four-digit levels of ISIC. ${ }^{5}$

\footnotetext{
${ }^{4}$ See Frankel and Rose (1997).

${ }^{5}$ The data are taken from the OECD database STAN. We have calculated the index using data for 1993.
} 
(Table 2 about here.)

Table 2 shows the degree of product diversification in a number of countries. We have included countries which are potential members of the European monetary union as well as countries which will not join. Countries which do not intend to join the European monetary union can be used as a comparison group.

Table 2 shows that Canada has the most diversified manufacturing structure, and Japan the least diversified. Potential members of the European monetary union do not in general seem to be characterised by a high degree of manufacturing diversification. Some have a relatively high degree of diversification, such as France and Italy, while other countries have a relatively low degree of diversification. Both Sweden and Finland exhibit a low degree of diversification. The result is not dependent on the choice of year. It changes only marginally when we investigate a five-year average for 1989-93.

(Chart 1 about here.)

Kotilainen (1996) points out that the Finnish industrial structure is characterised by an extensive paper and wood products industry. In Sweden also, these industries are of major importance. Chart 1 describes the industrial structure in Sweden, Finland and the EU countries (with an unweighted average that excludes Sweden and Finland).

As above, the fractions of the total production have been calculated using value added. ${ }^{6}$ The total industrial production is divided at the two-figure level by ISIC. ${ }^{7}$ The paper and wood product industry accounts for about $28 \%$ of all manufacturing production in Finland and about $21 \%$ in Sweden. The corresponding figure for the rest of the EU is about $12 \%$. The importance of forestry products is thus much greater in Sweden and Finland than in the other EU countries. In addition, forestry-related products are manufactured in other industrial sectors. For example, in 1990 the production of machinery for the paper industry amounted to $3 \%$ of the total manufacturing production in Finland (Kotilainen (1996, p. 115)). In sectors such as means of transport, chemical industry and metal industry there is also a considerable forestry-related element.

The engineering industry is also more important, primarily in Sweden but also in Finland, than in the other EU countries. The engineering industry accounts for $46 \%$ of total production in Sweden, 36\% in Finland and 33\% in the EU. While forestry-related production and engineering have a relatively great importance in Sweden and Finland, the opposite applies to the production of food products and textiles, in particular. Food products account for $12 \%$ of Finland's production and $8 \%$ of Sweden's, but $18 \%$ in the EU. Textiles account for $3 \%$ of the

\footnotetext{
${ }^{6}$ Data from the OECD database STAN.

${ }^{7}$ The figure for Luxembourg is not included. For Spain, the figure for production is used instead of the value added.
} 
manufacturing production in Finland, $2 \%$ of the production in Sweden and $8 \%$ of the production in the EU.

The low degree of product diversification in Sweden and Finland constitutes an argument against membership in a European currency union. If the forestry sector were to be subjected to an asymmetric shock, in the form of major falls or increases in prices, this could lead to considerable macroeconomic disturbances if the exchange rates for the Swedish and Finnish currencies could not be altered.

We have been using two criteria to determine the suitability for a particular country to join a monetary union. According to the theory of optimum currency areas, countries with flexible wages and prices plus a diversified industrial structure are good candidates for a monetary union. A high degree of inflexibility in wages and prices, and a low degree of product diversification, argue against participation in a monetary union. The calculations above thus indicate that Sweden and Finland are not very suitable candidates for a European monetary union.

If Sweden and/or Finland decide to join a monetary union, this should be one including countries with which they exhibit relatively great similarities. This takes us into the unionspecific criteria which should be fulfilled for a monetary union to be well functioning.

\section{Union-specific criteria}

The degree of factor flexibility. When economic disturbances occur, adjustments can be achieved by the migration of labour and capital. Financial capital is relatively mobile between European countries. This mobility has increased during the 1980s and 1990s in conjunction with the deregulation of capital markets. However, labour mobility is much more limited. Linguistic and cultural differences between European countries limit the international mobility of the workforce.

Let us look at the empirical picture. The migration of labour between Sweden and Finland has been relatively large. This migration has consisted principally of Finnish workers who have moved from Finland to Sweden and back again (Lundborg (1991)). Table 3 gives the number of foreign citizens in Sweden in 1994. Finland represents by far the largest population group, with more than four times as many persons as the next largest, Norway.

(Table 3 about here.)

The flow of people into and out of Sweden confirms the picture from Table 3. Table 4 shows that immigration to Sweden is greatest from Finland, followed by the other two Nordic neighbours Norway and Denmark. Emigration of Swedes flows chiefly to Norway, followed by the USA, Finland and Denmark. 
(Table 4 about here.)

By contrast with Sweden, immigration to Finland has been minor. Table 5 shows the number of foreign-born persons living in Finland, grouped according to country of birth. Persons born in Sweden constitute by far the largest group, with more than 26.000 persons. The next largest group, persons born in Germany, is only one tenth as large as the Swedish group. One difference by comparison with immigration to Sweden is that few people have emigrated to Finland from the other two Nordic countries, Norway and Denmark.

(Table 5 about here.)

Similarity of production structure. Countries with a diversified industrial structure are suitable candidates for a monetary union. The production structure is important in one other respect when forming a monetary union. Countries with a similar industrial structure may be expected to be similarly affected by sector-specific disturbances. It is therefore desirable that the members of a monetary union should exhibit industrial structures that are similar.

Next, we construct an index for Sweden and Finland showing the degree of difference from the industrial structure of other countries. This is defined as the degree of absolute difference in the countries' sector fractions of the total industrial production. For Sweden this index is constructed as:

Production difference (country j) $=1-\sum_{i=1}^{n}\left|\frac{V A_{i, \text { sweden }}}{\sum_{i=1}^{n} V A_{i, \text { sweden }}}-\frac{V A_{i, j}}{\sum_{i=1}^{n} V A_{i, j}}\right| \times \frac{1}{2}$,

where $\mathrm{i}=1, \ldots$, are industries and VA is the value added. A high value of the index, which can have values between 0 and 1, indicates that the industrial structure is similar to Sweden's. The measure has been calculated for the difference between Sweden/Finland and 12 other OECD countries. Our selection of countries includes, as before, both potential EMU members and countries which will not be joining EMU. Data from 19 different manufacturing industries at three and four-digit level of ISIC have been used. ${ }^{8}$

(Table 6 about here.)

According to Table 6, Finland's manufacturing structure is most similar to that of Sweden, followed by those in Norway and Austria. Finland's manufacturing structure exhibits a considerable similarity with those of some potential EMU members, such as Austria and the

\footnotetext{
${ }^{8}$ The data are taken from the OECD database STAN. We have calculated the index using data for 1993.
} 
Netherlands, but little similarity with those of some other potential members such as Italy.

Swedish manufacturing is most similar to that in the USA, followed by those in Finland and Germany. Sweden, like Finland, does not seem to show any marked similarity with potential EMU countries such as Italy. The choice of year has only a minor effect on the result. The use of a five-year average for the production fractions does not alter the general picture.

To summarise, Sweden and Finland do not show any great similarity with other potential EMU countries in comparison with countries which will not be joining the EMU. On the other hand, Sweden and Finland have similar manufacturing structures. As mentioned above, this is partly because forestry-related production and the engineering industry are relatively important in these two countries.

Cyclical covariation in economic activity. One measure of the covariation in economic activity is given by the correlation between production growth in different countries. In Table 7 we show the correlations between Sweden and 17 other OECD countries as regards the annual growth of industrial production during the period 1961-95. The corresponding correlations for Finland are given in Table 8. Growth in Sweden shows the greatest correlation with that in Finland. The correlation is high with some potential EMU members such as the Netherlands and Belgium. At the same time, the correlation is lower than average for other potential member countries such as France, Germany, Greece and Portugal. If we split the correlation in industrial growth into two different periods of time, the result is somewhat different. However, Sweden has a high correlation with Finland in both periods. Furthermore, Sweden does not have a particularly high correlation with potential EMU members in any time period.

(Table 7 about here.)

The growth in Finland's industrial production is most highly correlated with that in Sweden. As in the Swedish case, Finland does not in general exhibit a high correlation with potential EMU countries. The correlation is high with EU countries such as Austria and France, but low with others such as Great Britain, Ireland and Portugal. Furthermore, the correlation is high with some countries which will not be joining the EMU, like Switzerland and Canada. If we split the correlation into two different time periods, the result changes somewhat, but the correlation with Sweden remains very high in both periods.

(Table 8 about here.)

Since manufacturing industry accounts for a minor fraction of the processed value within OECD, the covariation in growth of the total economy should also be studied. In Table 9 we show the correlation between annual GDP growth for Sweden and 19 other OECD countries. For the whole period of 1961-95 we find, somewhat surprisingly, that Australia shows the greatest correlation with Sweden. Finland has the next highest correlation with Sweden. If we 
split the correlation into two different periods of time, the Swedish GDP growth is most closely correlated with that in Finland during the 1960s and 1970s, and with that in Australia during the 1980s and 1990s. Once again, we cannot detect any strong connection between potential members of the EMU and high correlation in GDP growth. The correlation with countries outside the EMU, such as Switzerland, USA and Canada, is high during the later period.

(Table 9 about here.)

The correlation with Finland's growth in GDP during the period 1961-95 is given in Table 10. The correlation has been greatest with Sweden. The high degree of correlation with the Swedish GDP growth applies regardless of the choice of period. The Finnish GDP growth has been highly correlated with certain potential EMU members such as Greece, Austria and France, but poorly correlated with other potential EMU members such as the Netherlands, Germany and Ireland.

Our earlier conclusions still hold. The correlation between Sweden and Finland is very high, irrespective of the choice of period, and this applies for both growth in GDP and industrial production. Our results are in accordance with some previous studies. Cheung and Hutchison (1995), Hassler (1996) and Pissarides (1996) use different methods to investigate the crosscountry correlations in business cycles and economic disturbances. All these studies find a high degree of correlation between Sweden and Finland. This indicates that Sweden and Finland exhibit a similar economic structure.

(Table 10 about here.)

Similarity of inflation. If Sweden and Finland were to join the European monetary union it would be desirable for their rates of inflation to be the same as in the rest of the EMU. However, it is not clear which rate of inflation will apply in the future EMU. There are strong indications that Germany's Bundesbank will dictate the EMU's monetary policy and, hence, inflation. It is therefore appropriate to compare the Swedish and Finnish rates of inflation with that in Germany.

Table 11 shows that between 1962 and 1994, the average inflation has amounted to $6.8 \%$ in Sweden, 7.2\% in Finland and 3.5\% in Germany. For the two periods 1962-79 and 1980-94, Germany had a considerably lower rate of inflation than Finland and Sweden in both periods. Finland and Sweden have exhibited a relatively large historical accordance as regards inflation. This can be due to the similarity in industrial structure and/or the similarity in economic policy. The similarity in rates of inflation between Sweden and Finland should mean that a currency union between these two countries would involve relatively low costs of adjustment.

(Table 11 about here.) 
Similarity of economic policy. One of the greatest changes from a membership in the EMU is the reduction in monetary independence. The Maastricht agreement (Article 103) states that, "the member countries shall consider economic policy to be a question of common interest and shall co-ordinate the same within the Council..." (Swedish Ministry for Foreign Affairs (1993, p.23)). For countries which have already been pursuing a similar economic policy, in particular one that resembles the German policy, it may be assumed that the change-over will be relatively easy; for other countries it is likely to be more difficult.

Within a monetary union, monetary policy will by definition be the same for all member countries. As mentioned earlier, it is assumed that Germany will be the "anchor" in the planned European monetary union. It is therefore of interest to compare the monetary policies of Finland, Sweden and Germany.

There are a number of measures which indicate the conduct of a country's monetary policy. One such measure is the rate of inflation. As seen above the rate of inflation suggests that Finland and Sweden have pursued a similar monetary policy in the past, by comparison with that in Germany. Another indicator is the nominal rate of interest, which is shown in Table 12. A high long-term nominal rate of interest indicates a history of inflationary monetary policy, while a low nominal long-term interest rate suggests a less inflationary monetary policy.

(Table 12 about here.)

If we use the nominal rate of interest as a measure of the conduct of monetary policy, Sweden and Finland are seen to have pursued a more expansionary monetary policy than Germany. This confirms our earlier conclusion that Sweden and Finland have pursued similar monetary policies.

At this point it is not clear how independent a country's fiscal policy might be if it joins the EMU. The EU has established minimum criteria for the member countries' fiscal policies. These aim in general at limiting budget deficits. Since fiscal policies will be affected by membership in the EMU, it is of interest to study how they have been pursued in Finland and Sweden. Table 12 shows the budget deficits as a fraction of GDP between 1961 and 1995 in Finland, Sweden and Germany. A large negative deficit can be regarded as an indicator of an expansionary fiscal policy, while a surplus indicates a restrictive fiscal policy.

The budget deficit as a fraction of the GDP during the period 1961-95 has been lowest in Germany and highest in Finland. Finland has thus pursued the most restrictive policy, and Germany the most expansionary. During the 1960s and 1970s, Sweden's fiscal policy was similar to that in Finland, but during the 1980s and 1990s it was more like the German policy.

Political and other factors. Perhaps the most important aspect when forming a monetary union is that it should be firmly established in the minds of the general public and the 
electorate (Cohen (1993)). Membership in a monetary union involves considerable changes in the setting of wage levels, economic policies, etc. These changes can be difficult to accept if there is not a sufficiently great feeling of affinity with the other member countries. In both Finland and Sweden there is a widespread mistrust of the EMU. Opinion polls in Sweden show that the majority of the population is opposed to membership. If Sweden were to join the EMU under these circumstances it could lead to political tension, particularly if the economic consequences of joining are felt to be negative.

We are inclined to believe that there are a number of reasons for supposing that a currency union or some other form of closer monetary co-operation between Finland and Sweden would meet with stronger support from the general public than membership in the EMU. Finland and Sweden have strong cultural, social and historical links. Finland and Sweden were one country for several centuries. This has contributed to a common legal and administrative tradition and a common religion. There are also linguistic ties between Finland and Sweden. Approximately 6\% of Finland's population are Swedish-speaking. Most Finns understand Swedish as well. Sweden has a large Finnish-speaking population, partly in the northern section of the country and partly among the large group which immigrated from Finland during the 1960s and 1970s. Finnish influences within Swedish culture are noticeable, and in the same way Finnish culture is oriented towards Sweden.

Summary: According to our analysis, Finland and Sweden are not any obvious candidates for membership in a European monetary union. According to the union-specific criteria which we have studied, there is no particular similarity between either Finland and the other EU countries or between Sweden and the other EU countries. Finland and Sweden exhibit, however, common characteristics which indicate that they would constitute an "optimum" currency area. The two countries have a similar economic structure, migration between them has been relatively great, they are situated next door to each other and they are roughly of the same size. They show considerable cultural and political similarities, and they have a common history. This suggests that Finland and Sweden constitute a suitable area for a common currency, and thus a variable exchange rate with the rest of the world, especially when comparing this with the alternative of Finland and Sweden becoming members of the EMU. A schematic comparison of a Finnish-Swedish currency union with a Finnish-Swedish membership of the EMU is presented in Table 13, which summarises the above discussion.

(Table 13 about here.)

\section{Are the advantages of a Finnish-Swedish currency union sufficiently great?}

On the basis of the theory of optimum currency areas, Finland and Sweden appear to constitute a suitable geographical area for a currency union. The criteria which we have used focus on the costs, i.e. the disadvantages of currency unions. By the costs we mean the risk of higher unemployment and economic stagnation resulting from the formation of a currency union, principally in cases of asymmetrical disturbances. These risks are minimised to the 
extent that the criteria are fulfilled according to Table 1.

Any decision on membership in a currency union should also consider the benefits, that is the economic gains for society which arise as a result of membership in a currency union. The benefits or advantages of having a common currency lie with the reduced costs of transactions and the lower uncertainty when trading and investing within the currency union, as pointed out in the introduction. The change-over to the Euro will for example eliminate the transaction costs of exchange between different currencies and any uncertainty about future exchange rates within the EMU. Opinions are rather divided as to the magnitude of these benefits. The EU commission (1990) estimated that exchange costs within the EU amounted to about $0.4 \%$ of GDP. However, this cost should have fallen and continue to fall in the future due to the development of financial technology.

Uncertainty about future exchange rates is said to involve a cost due to reduced international trade. There have been numerous empirical studies of the relationship between exchange rate variations and the amount of international trade. ${ }^{9}$ However, there is no consensus on the effects of exchange rate variations on the volume of trade. In those studies which do find negative effects, these are usually only minor.

If a monetary union leads to increased trade, this is an argument in favour of Sweden and Finland participating in the EMU instead of forming of currency union of their own. Both Sweden and Finland have a major fraction of their trade with the EU countries, but only a minor fraction with each other. Swedish trade with Finland amounts to about $5 \%$ of total Swedish international trade, while Finnish trade with Sweden amounts to about $10 \%$ of Finland's trade. Swedish and Finnish trade with the EU amounts to about $60 \%$ of each country's total trade. However, it is worth noting that the whole of the EU will probably not join the EMU; important trade partners for Finland and Sweden, like Denmark and Great Britain, will remain outside the monetary union, at least initially.

Another advantage of a membership in the EMU, which occupies a prominent place in the debate, is that the member countries would share German credibility as regards low inflation. Consequently interest rates would fall. A necessary condition for membership in the EMU is that the convergence criteria should be fulfilled. In brief, these mean that a country such as Finland or Sweden must have an inflation rate, public finances and interest rates that do not differ too much from those of other EU countries, if they are to become members of the EMU. These criteria have to be fulfilled by means of domestic economic policies before joining the EMU. It follows that they could also be achieved by means of successful economic policies if Finland and Sweden were to remain outside the EMU.

Finland and Sweden display strong interdependence as regards monetary policy. This is

\footnotetext{
${ }^{9} \mathrm{~A}$ review is given in Coté (1994).
} 
shown by the monetary development during the past 20 years. ${ }^{10}$ When the Swedish exchange rate has been changed through devaluations it has had repercussions on the Finnish economy, principally on the profitability of the forestry industry, and thus on Finnish monetary policy. If Finland were to join the ERM or EMU while Sweden remains outside, or vice versa, this would probably create economic and political tensions between the two countries in the long run. The economic relationship between Finland and Sweden is so strong that the two countries would benefit greatly from co-operation as regards monetary policy. This means that either they should both have a flexible exchange rate, or they should have a completely pegged rate, in other words establish some form of exchange rate union.

Taken together, the expected economic advantages associated with Finnish and Swedish participation in the EMU seem to be limited by comparison with a Finnish-Swedish monetary union. Instead it is probably more relevant to stress the political advantages which could be associated with the membership in EMU. Politicians in Europe have emphasised that the introduction of a common currency will represent a central part of the deepened political union in EU. At the same time it is clear from the present study that for Finland and Sweden participation in EMU is associated with major risks, greater than for countries in central Europe.

There is much to be said for Finland and Sweden forming a monetary union as a preliminary to either joining or remaining outside the EMU. ${ }^{11}$ It is tempting to suggest that not until a monetary union between these two countries is functioning well should any membership in EMU be considered. If a monetary union between Sweden and Finland gives rise to macroeconomic difficulties, in spite of the large similarities between these two countries, then participation in EMU would appear to be an even more hazardous project from a Finnish and Swedish perspective.

A central conclusion to be drawn from our examination is that the Finnish and Swedish economies exhibit considerable similarities in relation to other EU countries, and thus potential EMU members. This points to the importance of a Finnish-Swedish co-operation in matters of monetary policy. This co-operation can be constructed in different ways. A formal currency union with a common central bank and a common Finnish-Swedish currency, a "kronmark", is one course which appears consistent with the theory of optimum currency areas. Another method is to create an authority which co-ordinates the policies of the two countries' central banks. There is space here for different institutional arrangements.

\footnotetext{
${ }^{10}$ See here for example the analysis of Finland's economic crisis during the 1990s by Söderström (1993) and the comparison between the course of events during the crisis in Sweden and Finland in Jonung, Söderström and Stymne

${ }^{11}$ This conclusion has also been put forward by Bordes (1993, p. 86).
} 


\section{References}

Bayoumi, T. och Eichengreen, B., (1997), "Optimum Currency Areas and Exchange Rate Volatility: Theory and Evidence Compared" , Mimeo, International Monetary Fund, Washington D.C.

Bordes, C. (1993), "The Finnish Economy: The Boom, the Debt, the Crisis and the Prospects." in Bordes, C., Currie, D. and Tson Söderström, H. (1993), Three Assessments of Finland's Economic Crisis and Economic Policy, Bank of Finland, Helsinki.

Bordo, M. and Jonung, L. (1997), "The History of Monetary Regimes - Some Lessons for Sweden", Swedish Economic Policy Review, Vol. 4, pp. 285-359.

Cheung, Y. W. och Hutchison, M., (1995), "Should the Nordic Countries Join A European Monetary Union? An Empirical Analysis", Mimeo, Department of Economics, University of California Santa Cruz.

Cohen, B. (1993), "Beyond EMU: The Problem of Sustainability", Economics and Politics, 5, 187-202.

Coté, A., (1994), "Exchange Rate Volatility and Trade: A Survey", Working Paper no 94-5, International Department, Bank of Canada.

EU-commission, (1990), "One Market, One Money - An Evaluation of the Potential Costs and Benefits of Forming an Economic and Monetary Union", European Economy, 44, Bryssel.

Flemming, J.M. (1971), "On Exchange Rate Unification", Economic Journal, 81, 467-488.

Frankel, J. och Rose, A., (1997), ”Is EMU More Justifiable Ex Post Than Ex Ante?", European Economic Review, 41, 753-60.

Hassler, J., (1997), "International covariation in manufacturing 1975-1995", Swedish Economic Policy Review, Vol. 4. pp. 411-447.

Jonung, L., Söderström, H. and Stymne, J. (1996), "Depression in the North - Boom and Bust in Sweden and Finland, 1985-93", Finnish Economic Papers, Vol. 9, No. 1.

Kenen, P.B. (1969), "The Theory of Optimum Currency Areas: An Eclectic View", in Mundell, R.A. and A.K. Swoboda (ed.), Monetary Problems of the International Economy", University of Chicago Press. 
Kotilainen, M. (1996), "Is the EU an Optimal Currency Area and is Finland a PArt of it?", in Ahlo, K., Erkkilä, M. and Kotilainen, M. (ed.), "The Economics and Policies of Integration A Finnish Perspective", Kluwer Academic Publishers.

Lundborg, P. (1991), "Determinants of Migration in the Nordic Labor Market", Scandinavian Journal of Economics, Vol 93, pp. 363-75.

Mintz, N. (1970), "Monetary Union and Economic Integration", New York University Press.

Mundell, R.A. (1961), "Theory of Optimum Currency Areas", American Economic Review, 51, 657-65.

Pissarides, C., (1996), "The Need for Labor-market Flexibility in a European Economic and Monetary Union", Swedish Economic Policy Review, Vol. 4, pp. 513-547.

Söderström, H. (1993), "Finland's Economic Crisis: Causes, present nature, and policy options", in Bordes, C., Currie, D. and Tson Söderström, H. (1993), Three Assessments of Finland's Economic Crisis and Economic Policy. Bank of Finland, Helsinki.

Statistics Finland, Statistical Yearbook of Finland 1995, Helsinki.

Statistics Sweden, Statististical Yearbook of Sweden 1995, Stockholm.

Statistics Sweden, Population statistics 1995, Stockholm.

Swedish Ministry of Foreign Affairs (1993), Maastrichtfördraget - Fördraget om Europeiska unionen. Regeringskansliets Offsetcentral, Stockholm.

Tavlas, G.S. (1993), "The 'New' Theory of Optimum Currency Areas", The World Economy, vol. 16 , p. 663-685. 
Table 1. Criteria for an optimum currency area.

\begin{tabular}{|l|l|}
\hline Country-specific criteria & $\begin{array}{l}\text { High flexibility in wages and prices } \\
\text { High degree of product diversification }\end{array}$ \\
\hline Union-specific criteria & High mobility of production factors \\
& Similar industry structures \\
& High covariation in economic activity \\
& Similar economic policy preferences \\
& Similar cultural and historical factors
\end{tabular}

Source: Tavlas (1993) and Bayoumi and Eichengreen (1997). 
Table 2. Degree of product diversification, 1993.

\begin{tabular}{|l|lr|}
\hline High degree of & Europe & \\
Diversification & France & 10.2 \\
& Italy & 10.3 \\
& U.K. & 10.9 \\
& Germany & 11.1 \\
& Austria & 11.2 \\
& Netherlands & 11.6 \\
Low degree of & Norway & 11.9 \\
Diversification & Sweden & 12.3 \\
& Denmark & 13.1 \\
& Finland & 14.0 \\
& & \\
& Average Europe & 11.7 \\
& & \\
& Rest of the & \\
& world & 9.3 \\
& Canada & 9.5 \\
& Austria & 11.3 \\
& U.S. & 16.1 \\
& Japan & \\
& & \\
& & \\
& Total average & \\
&
\end{tabular}

Source: OECD STAN. Comments: Calculated according to equation 1. 
Table 3. Population in Sweden according to country of birth, number of persons, 1994.

\begin{tabular}{|lr|}
\hline Finland & 236079 \\
Norway & 53553 \\
Denmark & 47863 \\
Germany & 38843 \\
U.S. & 15093 \\
Great Britain & 14226 \\
Greece & 13593 \\
Austria & 7064 \\
Italy & 6881 \\
Spain & 5450 \\
Iceland & 5206 \\
France & 4692 \\
Netherlands & 4202 \\
Switzerland & 2871 \\
Portugal & 2756 \\
\hline
\end{tabular}

Source: SCB (Swedish Central Statistical Bureau), Annual statistics, 1995. 
Table 4. Migration to and from Sweden, number of persons, 1995.

\begin{tabular}{|lrrr|}
\hline Country & Immigration & Emigration & Total migration \\
\hline Norway & & & \\
Finland & 2674 & 4383 & 6057 \\
U.S. & 3165 & 3439 & 5704 \\
Denmark & 2200 & 3503 & 4982 \\
Great Britain & 2354 & 2628 & 3305 \\
Germany & 1498 & 1807 & 3091 \\
Spain & 1672 & 1419 & 1564 \\
France & 656 & 908 & 1516 \\
Greece & 790 & 726 & 1277 \\
Iceland & 484 & 793 & 1137 \\
Netherlands & 567 & 570 & 897 \\
Italy & 482 & 415 & 869 \\
Austria & 429 & 440 & 350 \\
\hline
\end{tabular}

Source: SCB (Swedish Central Statistical Bureau), Population statistics for 1995. Immigration and Emigration. 
Table 5: Population in Finland according to country of birth, 1994.

\begin{tabular}{|lr|}
\hline Sweden & 26164 \\
Germany & 2680 \\
USA & 2662 \\
Great Britain & 2011 \\
Norway & 845 \\
France & 673 \\
Italy & 614 \\
Spain & 599 \\
Denmark & 560 \\
Switzerland & 475 \\
Netherlands & 435 \\
Greece & 388 \\
\hline
\end{tabular}

Source: Statistiskcentralen, Statistisk Årsbok för Finland 1995 (Finnish annual statistics) 
Table 6. Degree of similarity in industrial structure, 1993.

\begin{tabular}{|c|c|c|c|}
\hline $\begin{array}{l}\text { Finish production } \\
\text { differences }\end{array}$ & & $\begin{array}{l}\text { Swedish production } \\
\text { differences }\end{array}$ & \\
\hline Europe & & Europe & \\
\hline Sweden & 0.85 & Finland & 0.85 \\
\hline Norway & 0.84 & Germany & 0.83 \\
\hline Austria & 0.79 & Norway & 0.81 \\
\hline Netherlands & 0.78 & Austria & 0.80 \\
\hline Germany & 0.76 & Great Britain & 0.78 \\
\hline Great Britain & 0.76 & France & 0.78 \\
\hline France & 0.75 & Netherlands & 0.76 \\
\hline Denmark & 0.74 & Italy & 0.74 \\
\hline Italy & 0.70 & Denmark & 0.71 \\
\hline Average & & Average & \\
\hline Europe & 77.4 & Europe & 78.4 \\
\hline Rest of the world & & Rest of the world & \\
\hline USA & 0.77 & USA & 0.86 \\
\hline Canada & 0.75 & Canada & 0.79 \\
\hline Japan & 0.73 & Japan & 0.79 \\
\hline Australia & 0.71 & Australia & 0.73 \\
\hline Total Average & 0.76 & Total Average & 0.79 \\
\hline
\end{tabular}

Source: OECD STAN. 
Table 7. Annual growth in Swedish industrial production. Correlation with the rest of the world, 1961-95.

\begin{tabular}{|c|c|c|c|c|c|}
\hline & $1961-1995$ & & 1961-1979 & & $1980-1995$ \\
\hline Europe & & Europe & & Europe & \\
\hline Finland & 0.69 & Finland & 0.67 & Ireland & 0.74 \\
\hline Netherlands & 0.54 & Netherlands & 0.61 & Finland & 0.72 \\
\hline Belgium & 0.53 & Belgium & 0.53 & Spain & 0.69 \\
\hline Ireland & 0.5 & Austria & 0.49 & Belgium & 0.59 \\
\hline Austria & 0.5 & Switzerland & 0.47 & Italy & 0.58 \\
\hline Spain & 0.45 & France & 0.45 & Netherlands & 0.58 \\
\hline Switzerland & 0.45 & Germany & 0.43 & Austria & 0.55 \\
\hline Italy & 0.43 & Spain & 0.4 & Great Britain & 0.51 \\
\hline Great Britain & 0.43 & Italy & 0.33 & Norway & 0.43 \\
\hline France & 0.41 & Great Britain & 0.32 & Switzerland & 0.43 \\
\hline Germany & 0.39 & Greece & 0.31 & France & 0.39 \\
\hline Norway & 0.34 & Ireland & 0.23 & Greece & 0.37 \\
\hline Greece & 0.27 & Norway & 0.22 & Germany & 0.33 \\
\hline Portugal & 0.10 & Portugal & 0.12 & Portugal & 0.03 \\
\hline Average Europe & 0.43 & Average Europe & 0.40 & Average Europe & 0.50 \\
\hline Rest of the world & & Rest of the world & & Rest of the world & \\
\hline Canada & 0.50 & Japan & 0.54 & U.S. & 0.64 \\
\hline Japan & 0.43 & Canada & 0.34 & Canada & 0.64 \\
\hline U.S. & 0.24 & U.S. & -0.04 & Japan & 0.31 \\
\hline Total average & 0.42 & Total average & 0.38 & Total average & 0.50 \\
\hline
\end{tabular}

Souce: OECD, Main Economic Indicators. 
Table 8. Annual growth in Finnish industrial production. Correlation with the rest of the world, 1961-95.

\begin{tabular}{|c|c|c|c|c|c|}
\hline \multicolumn{2}{|c|}{$1961-1995$} & \multicolumn{2}{|c|}{ 1961-1979 } & \multicolumn{2}{|c|}{ 1980-1995 } \\
\hline Europe & & Europe & & Europe & \\
\hline Sweden & 0.69 & Austria & 0.78 & Sweden & 0.72 \\
\hline Switzerland & 0.59 & Switzerland & 0.72 & Italy & 0.52 \\
\hline Austria & 0.56 & Belgium & 0.67 & Spain & 0.42 \\
\hline France & 0.54 & Sweden & 0.67 & Switzerland & 0.42 \\
\hline Belgium & 0.54 & France & 0.66 & Great Britain & 0.38 \\
\hline Spain & 0.51 & Netherlands & 0.65 & Ireland & 0.38 \\
\hline Netherlands & 0.5 & Germany & 0.64 & Greece & 0.38 \\
\hline Italy & 0.48 & Spain & 0.51 & Norway & 0.34 \\
\hline Greece & 0.41 & Portugal & 0.45 & France & 0.23 \\
\hline Germany & 0.39 & Italy & 0.39 & Belgium & 0.23 \\
\hline Great Britain & 0.39 & Ireland & 0.37 & Austria & 0.17 \\
\hline Ireland & 0.33 & Great Britain & 0.34 & Netherlands & 0.12 \\
\hline Portugal & 0.29 & Greece & 0.34 & Germany & -0.08 \\
\hline Norway & 0.26 & Norway & 0.2 & Portugal & -0.08 \\
\hline Average & & Average & & Average & \\
\hline Europe & 0.46 & Europe & 0.53 & Europe & 0.30 \\
\hline Rest of the world & & Rest of the world & & Rest of the world & \\
\hline Canada & 0.51 & Japan & 0.56 & Canada & 0.51 \\
\hline Japan & 0.45 & Canada & 0.42 & USA & 0.5 \\
\hline USA & 0.36 & USA & 0.22 & Japan & 0.1 \\
\hline Total Average & 0.46 & Total Average & 0.51 & Total Average & 0.31 \\
\hline
\end{tabular}

Source: OECD: Main Economic Indicators. 
Table 9. Annual growth in Swedish GDP. Correlation with the rest of the world, 1961-95.

\begin{tabular}{|c|c|c|c|c|c|}
\hline \multicolumn{2}{|c|}{$1961-1995$} & \multicolumn{2}{|c|}{ 1961-1979 } & \multicolumn{2}{|c|}{ 1980-1995 } \\
\hline Europe & & Europe & & Europe & \\
\hline Finland & 0.7 & Finland & 0.7 & Finland & 0.7 \\
\hline Netherlands & 0.55 & Netherlands & 0.5 & Great Britain & 0.67 \\
\hline France & 0.54 & France & 0.47 & Greece & 0.67 \\
\hline Denmark & 0.46 & Switzerland & 0.43 & Italy & 0.59 \\
\hline Greece & 0.43 & Denmark & 0.39 & Switzerland & 0.44 \\
\hline Switzerland & 0.43 & Germany & 0.38 & Spain & 0.42 \\
\hline Italy & 0.42 & Austria & 0.36 & Denmark & 0.37 \\
\hline Great Britain & 0.41 & Greece & 0.3 & Netherlands & 0.36 \\
\hline Spain & 0.41 & Spain & 0.28 & Turkey & 0.34 \\
\hline Austria & 0.41 & Great Britain & 0.25 & France & 0.31 \\
\hline Germany & 0.33 & Italy & 0.24 & Norway & 0.29 \\
\hline Portugal & 0.26 & Portugal & 0.18 & Ireland & 0.13 \\
\hline Norway & 0.21 & Norway & -0.13 & Austria & 0.06 \\
\hline Turkey & 0.08 & Turkey & -0.14 & Portugal & -0.03 \\
\hline Ireland & -0.03 & Ireland & -0.24 & Germany & -0.05 \\
\hline Europe & & Europe & & Europe & \\
\hline Average & 0.37 & Average & 0.26 & Average & 0.35 \\
\hline Rest of the world & & Rest of the world & & Rest of the world & \\
\hline Australia & 0.72 & Australia & 0.69 & Australia & 0.79 \\
\hline Japan & 0.54 & Japan & 0.52 & USA & 0.71 \\
\hline Canada & 0.43 & New Zealand & 0.18 & Canada & 0.67 \\
\hline New Zealand & 0.23 & Canada & 0.07 & New Zealand & 0.34 \\
\hline USA & 0.2 & USA & -0.17 & Japan & 0.12 \\
\hline Total Average & 0.41 & Total Average & 0.28 & Total Average & 0.42 \\
\hline
\end{tabular}

Source: OECD, Main Economic Indicators. 
Table 10. Annual growth in Finnish GDP. Correlation with the rest of the world, 1961-95.

\begin{tabular}{|c|c|c|c|c|c|}
\hline \multicolumn{2}{|c|}{ 1961-1995 } & \multicolumn{2}{|c|}{ 1961-1979 } & \multicolumn{2}{|c|}{ 1980-1995 } \\
\hline Europe & & Europe & & Europe & \\
\hline Sweden & 0.7 & Sweden & 0.7 & Greece & 0.9 \\
\hline Greece & 0.68 & Switzerland & 0.59 & Sweden & 0.71 \\
\hline France & 0.54 & Germany & 0.55 & Switzerland & 0.55 \\
\hline Switzerland & 0.54 & Austria & 0.55 & France & 0.49 \\
\hline Great Britain & 0.42 & France & 0.53 & Italy & 0.48 \\
\hline Spain & 0.42 & Spain & 0.44 & Great Britain & 0.48 \\
\hline Austria & 0.41 & Greece & 0.39 & Spain & 0.24 \\
\hline Italy & 0.36 & Denmark & 0.36 & Portugal & 0.23 \\
\hline Portugal & 0.32 & Great Britain & 0.31 & Ireland & 0.07 \\
\hline Denmark & 0.28 & Netherlands & 0.29 & Denmark & 0.04 \\
\hline Netherlands & 0.26 & Portugal & 0.27 & Austria & -0.01 \\
\hline Germany & 0.19 & Italy & 0.24 & Netherlands & -0.03 \\
\hline Ireland & 0.04 & Ireland & -0.08 & Turkey & -0.06 \\
\hline Norway & 0.03 & Norway & -0.14 & Norway & -0.09 \\
\hline Turkey & -0.17 & Turkey & -0.37 & Germany & -0.46 \\
\hline Average Europe & & Average Europe & & Average Europe & \\
\hline & 0.33 & & 0.31 & & 0.24 \\
\hline Rest of the world & & Rest of the world & & Rest of the world & \\
\hline Australia & 0.58 & Australia & 0.45 & Australia & 0.63 \\
\hline Canada & 0.4 & Japan & 0.42 & New Zealand & 0.51 \\
\hline Japan & 0.37 & New Zealand & 0.21 & Canada & 0.49 \\
\hline New Zealand & 0.23 & Canada & 0.13 & USA & 0.33 \\
\hline USA & 0.19 & USA & -0.04 & Japan & 0.06 \\
\hline Total average & 0.34 & Total average & 0.29 & Total average & 0.28 \\
\hline
\end{tabular}

Source: OECD, Main Economic Indicators. 
Table 11. Rates of Inflation (\%, average value), 1962-94.

\begin{tabular}{|l|l|l|l|}
\hline Country & $1962-1994$ & $1962-1979$ & $1980-1994$ \\
\hline Finland & $7.2 \%$ & $8.3 \%$ & $6.0 \%$ \\
\hline Sweden & $6.8 \%$ & $6.5 \%$ & $7.2 \%$ \\
\hline Germany & $3.5 \%$ & $3.9 \%$ & $3.1 \%$ \\
\hline
\end{tabular}

Source: OECD, Main Economic Indicators. 
Table 12. Average nominal rate of interest and budget deficit as a fraction of GDP, 1961-95 (\%, average value).

\begin{tabular}{|c|c|c|c|c|c|c|}
\hline & \multicolumn{3}{|c|}{$\begin{array}{l}\text { Interest } \\
\text { rate }\end{array}$} & \multicolumn{3}{|c|}{\begin{tabular}{|l} 
Budget \\
deficit
\end{tabular}} \\
\hline & $\begin{array}{l}1961- \\
1995\end{array}$ & $\begin{array}{l}1961- \\
1979\end{array}$ & $\begin{array}{l}1980- \\
1995\end{array}$ & $\begin{array}{l}1961- \\
1995\end{array}$ & $\begin{array}{l}1961- \\
1979\end{array}$ & $\begin{array}{l}1980 \\
1995\end{array}$ \\
\hline Sweden & 9.4 & 7.5 & 11.5 & 0.2 & 3.1 & -3.2 \\
\hline Finland & 9.4 & 8.5 & 10.4 & 2.5 & 4.1 & 0.5 \\
\hline Germany & 7.5 & 7.4 & 7.6 & -1.5 & -0.7 & -2.4 \\
\hline
\end{tabular}

Källa: OECD, Economic Outlook. 
Table 13. A Finnish-Swedish currency union compared with a Finnish-Swedish membership in the EMU.

\begin{tabular}{|c|c|c|}
\hline $\begin{array}{l}\text { Criteria according to the theory of optimum } \\
\text { currency areas }\end{array}$ & $\begin{array}{l}\text { Within a Finish- } \\
\text { Swedish monetary } \\
\text { union }\end{array}$ & \begin{tabular}{|l|} 
Within a \\
European \\
monetary \\
union (EMU) \\
\end{tabular} \\
\hline $\begin{array}{l}\text { Degree of factor mobility } \\
\text { Similarity of production structure } \\
\text { Similarity of cyclical fluctuations } \\
\text { Similarity of inflation } \\
\text { Similarity of economic policies } \\
\text { Similarity of political, cultural and religious } \\
\text { factors }\end{array}$ & $\begin{array}{l}\text { High } \\
\text { Large } \\
\text { Large } \\
\text { Large } \\
\text { Large } \\
\text { Large }\end{array}$ & $\begin{array}{l}\text { Low } \\
\text { Lower } \\
\text { Small } \\
\text { Lower } \\
\text { Small } \\
\text { Small }\end{array}$ \\
\hline
\end{tabular}


Chart 1. Industry shares of total manufacturing production 1993

(\%).

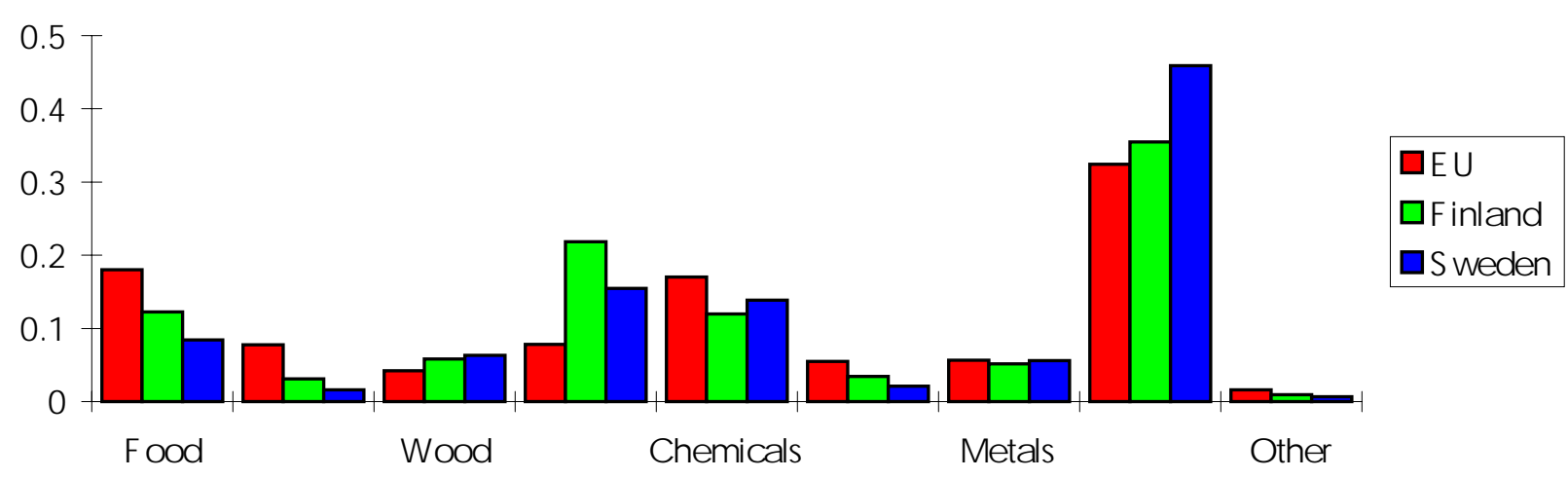

